Saša Jakovljević

Milivoje Karalejić

Zoran Pajić

796.323 .054

Radivoj Mandić

Original scientific paper

Faculty of Sport and Physical Education, University of Belgrade

\title{
ACCELERATION AND SPEED OF CHANGE OF DIRECTION AND THE WAY OF MOVEMENT OF QUALITY BASKETBALL PLAYERS
}

\begin{abstract}
The aim of this survey was to examine the ability of acceleration and the agility of basketball players. The survey was conducted on a sample of 35 professional Bulgarian basketball players (average age $21.37 \pm 2.91$ years) who competed in the First Bulgarian Basketball League and were divided into two groups depending on the position of the game: inner players $-\mathrm{N}=13$ and outer players - $\mathrm{N}=22$. They were chosen by experts as the best national players in the league. Two tests were applied: 20 meter run (acceleration - T20m) and T-test (agility - TT). During the 20- meter run test, the running times of five (T5m) and 10 meters (T10m) were measured. In addition, body height $(\mathrm{BH})$ and body mass $(\mathrm{BM})$ were measured. Inner players were significantly taller and heavier than the outer players, but no statistically significant differences were found between the two groups of players in the acceleration and agility variables, having in mind that on all the tests outer players achieved better results. High correlations were found between three acceleration variables $(\mathrm{T} 5 \mathrm{~m}$, T10m and $\mathrm{T} 20 \mathrm{~m}$ ) and one agility variable (TT) - correlation coefficients of .666 to .819 at the significance level of .01. The correlations between body height and acceleration variables are medium - correlation coefficients of .306 to .383 , at the significance level of .05 , while the correlation coefficients between body mass and these variables are slightly higher .350 to .415 at the significance level of .01 , or .05 .
\end{abstract}

Keywords: SENIORS / 20m / T TEST / CORRELATIONS / DIFFERENCES

\section{INTRODUCTION}

Basketball belongs to the group of sports games, which usually includes the so-called collective (team) sports, which contain direct 'fight' of two groups of people, two teams. It is a popular sports game, and its appeal to viewers is, basically, based on a pronounced game dynamics, variability and unpredictability of the situations in the game. Basketball stands out as an extremely complex game, with very specific structural and functional characteristics (Trninic, 1996). It includes intermittent and sophisticated moving activities with the complex requirements for a combination of individual skills, team play and motivational aspects (Trninic \& Dizdar, 2000). The structure of the game of basketball is commonly viewed in terms of type and duration of movement through time and movement analysis of common movements and through the analysis of specific basketball technical and tactical activities (Karalejic, and Jakovljevic, 2009). Success in high number of game tasks is accomplished by quick actions in a relatively small space (Trninić, et al., 2010b). Time and movement analysis refers to the registration and 
recording of the duration and distances passed by performing usual movement structures with and without the ball. Thus McInes et al. (McInes, Carlson, Jones, $\&$ McKenna, 1995) registered $997 \pm 183$ different actions of an individual during a basketball game, and Ben Abdelkrim et al. (Ben Abdelkrim, ElFazaa, \& ElAti, 2007) $1050 \pm 51$, after a change of rules (offence time reduced from 30 to 24 seconds, reduced time to transfer the ball into the frontcourt from 10 to 8 seconds and game distribution in four quarters instead of two halves). Basketball has plenty of: acceleration, deceleration, sprints, quick direction changes and rebounds. Krisafuli et al. (Crisafulli, Melis, Tocco, Laconi, Lai \& Concu, 2002) have found that basketball players, during the 40 minutes of a basketball game, cover about 4500-5000 $\mathrm{m}$ in different types of movement (changes of direction and course of movement, running, dribbling, defensive movements and rebounds) and at different, variable speeds. Narazaki et al. (Narazaki, Berg, Stergiou, \& Chen, 2008) provide information that players during a match spend $34 \%$ of the time in running and rebounding, $56.8 \%$ in walking and $9 \%$ of the time in standing still. It is clear that the game of basketball consists of short but very intense activities, broken by longer or shorter periods of passive or active rest, during which a basketball player recovers (Spencer, Bishop, Dawson, \& Goodman, 2005; Taylor, 2004; Trninic, 1996). In reference to this, basketball 'live' activity mainly takes place in the maximal and submaximal intensity. The intensity of the activities of players during the game is illustrated by the fact that approximately $75 \%$ of 'live' game time players spend in activities in which the pulse reaches the value of $85 \%$ or more of maximum heart rate (Erculj, Dezman, Vuckovic, Milic, 2002; McInes et al., 1995). Because of all this, coaches in basketball are advised to avoid using exercises that last longer than 30 seconds in the physical condition training programs, but to focus on short and intense activities and tests such as vertical rebound, $\mathrm{T}$ test, sprints in very short distances ( 5 to $20 \mathrm{~m}$ ) and the like (Delextrat, \& Cohen, 2008).

In relation to the basic motor structures, basketball belongs to the group of poly-structural sports where complex spatial movements dominate. Basketball player has to apply the learned movement structures (elements of technique and tactics) in different situations, which are changed during the game depending on the actions of teammates and opposing players. Fast linear (and arc) movements and movements with rapid changes in direction and course of movement, are almost always present in the actions of basketball players, individually or in various combinations. Speed of change of direction is of great importance in basketball because of high number of atypical situations that occur during the game. In addition, players often have to change the way of movement (e.g. frontal, lateral, movements 'backwards'). They usually need to perform multiple and rapid changes of direction on a relatively small area. An aggravating factor is that they also need to consider the technical and tactical aspect of the movement at the same time, because only in this way will their actions be effective. Because of this, basketball practice is also full of agility exercises, where players change the direction and the way of movement and full of exercises of acceleration, power, development of perception and ability to make optimal decisions (Young, \& Farrow, 2006). The course of the basketball game means continuity in the offense and defense phases, or in stages of transition (Trninić et al., 2010a). Highly developed ability to accelerate is of great importance not only for outer players, but for those who play on inner positions (centres). The reason for this is growing number of coaches who, because of the aforementioned shortening of the duration of the offence in basketball, are favouring rapid transition in the offence, but also in the defence. The idea is to reach the basket as soon as possible (in game situations 2 on 2 or 3 on 3), that is, before a complete defence is formed (game 5 on 5). On the other hand, in the transition defence the idea is that as soon as possible all five players return to the field of defence and organize the defence in position game. It cannot be achieved if the inner players are not able to run fast. In relation to the size of a basketball court ( $28 \times 15$ meters), that is, even less space to play (from one basket to the other), their ability to run fast, in fact, means the ability to accelerate. For outside players it is generally supposed to run and accelerate fast. Generally, basketball is a team sport of above-average tall people (Erčulj, \& Bračič, 2010), and inside players are very tall, so coaches must have a special attention for their speed training.

The speed of linear motion and the speed of direction change (agility) were identified as two specific qualities of athletes with mutual limited transfer (Young, Hawken, \& McDonald, 1996). There are a 
number of studies that are specific in the area of testing these skills, emphasizing the need to distinguish between the speed and agility tests (Draper \& Lancaster, 1985; Draper, \& Pyke, 1988; Mayhew, Piper, Schwegler, \& Ball, 1989).

The first aim of this survey was to examine the ability of acceleration and the speed of direction change of professional players (two types of players - outer and inner) and the other one was to examine relations between these two skills.

\section{METHOD}

\section{The sample of subjects}

The survey was conducted on a sample of 35 professional Bulgarian basketball players (average age $21.37 \pm 2.91$ years) who competed in the First Bulgarian Basketball League. They were selected by the basketball experts of Bulgarian Basketball Federation as the best national players in the league. The subjects were divided into two subgroups according to the position in the game: outer players (those who play in positions 1,2 and $3-\mathrm{N}=22$ ), average age $20.90 \pm 2.09$ years, and inner players (those who play in positions 4 and $5-\mathrm{N}=13$ ), average age 3.91 years \pm 22.15 .

\section{The sample of variables and measurement procedures}

Two tests were applied: 20 -meter sprint run and T-test. The test 20-meter sprint run was conducted on a marked track in a basketball hall, with photocells (Micro Gate, Italy) positioned at 5, 10 and 20 meters from the starting line and at a height of 1 meter. The subjects started from a standing position with a foot sticking out at a distance of $70 \mathrm{~cm}$ from the first photocell and were assigned to run as quickly as they can the distance of 20 meters. In that way, three variables were acquired, expressed in seconds(s): running time of 5 meters $(\mathrm{t} 5 \mathrm{~m})$, running time of 10 meters $(\mathrm{t} 10 \mathrm{~m})$ and running time of 20 meters $(\mathrm{t} 20 \mathrm{~m})$.

T-test (Figure 1) represents the agility test often used by trainers and researchers in sport. It is particularly applicable in testing basketball players because it contains movements that are very similar to the movements of players in the game. Four cones (stands), a stopwatch or photocells were need- ed. Cones were placed as in Figure 1. The subjects were properly warmed up and ready before the test. A surveyor or somebody else demonstrated the way of performance. Each subject was thus instructed to start, on the sign of the surveyor, from the point A and sprint to the cone $\mathrm{B}$, and to touch it with his right hand. Then, to move sliding sideways (basic basketball defence motion) to the cone $\mathrm{C}$ and touch it with his left hand. He then moves sideways to the cone $\mathrm{D}$ and touches it with his right hand. He goes again to the cone $\mathrm{B}$, touches it with his left hand and goes back to the cone A (backwards) and when he passes the cone A level the time of the performance of the whole test was registered. The test was performed in two attempts and the better result was taken into consideration. This way, a variable of fast change of direction and the way of movement (FCDA) was acquired.

In addition, what is measured was body height (BH), using stadiometer (Seca 220, UK) and body weight (BW), using portable scales (Tanita BF683W, GER). The variable 'body mass index' - BMI (body mass / body height ${ }^{2}$, in $\mathrm{kg} / \mathrm{m}^{2}$ ) was calculated from these two variables.

Figure $1 \mathrm{~T}$ - test

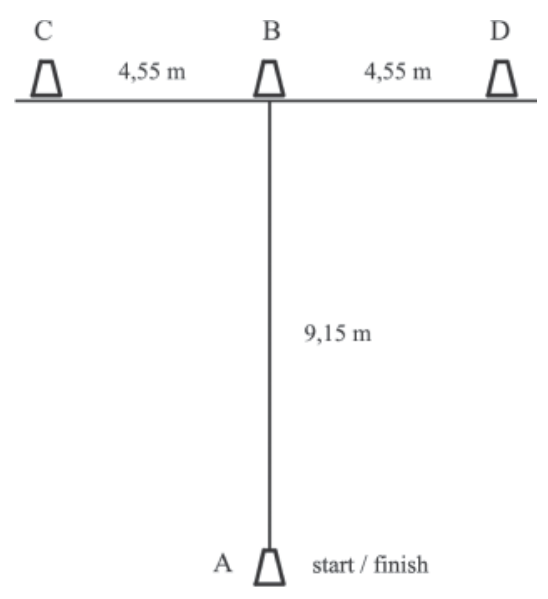

\section{Data analysis}

The data were firstly processed by basic descriptive statistics, where the following were calculated: arithmetic mean (M), standard deviation (SD), minimum (Min) and maximum values (Max). Relations between variables were tested using Pearson correlation coefficient. In examining the differences between the two groups of players $t$ test was used. Levels of significance were set at $\mathrm{p}<0.05$. 


\section{RESULTS AND DISCUSSION}

Table 1 shows the descriptive parameters of all the variables for the whole sample. Comparing the results from the available references it can be said that the subjects at a distance of 5 meters achieved very similar results (slightly lower) compared to, for example Australia's top basketball players, while the results of running 20 meters are very similar, almost identical (Stapff, 2000). It is similar in terms of body height and mass (Stapf, 2000).

Table 1 Descriptive parameters of all the variables for the whole sample

\begin{tabular}{ccccc}
\hline Variables & Min & Max. & Mean & SD \\
\hline t5m (s) & .96 & 1.18 & 1.0586 & .059 \\
t10m (s) & 1.68 & 2.00 & 1.8034 & .081 \\
t20m (s) & 2.81 & 3.48 & 3.0566 & .129 \\
BPPA (s) & 8.52 & 10.50 & 9.1143 & .395 \\
TV (cm) & 181.00 & 208.00 & 197.1714 & 6.345 \\
TM $(\mathrm{kg})$ & 75.50 & 122.00 & 93.9229 & 11.079 \\
BMI $\left(\mathrm{kg} / \mathrm{m}^{2}\right)$ & 20.41 & 28.24 & 24.13 & 2.18 \\
\hline
\end{tabular}

Descriptive parameters of sub-samples: the outer and inner players are presented in Ta- ble 2, as well as the values of t-test. Inner players are statistically significantly taller and heavier. This is expected regarding the usual division of roles in the game according to positions. Outer players showed better results on average in the acceleration variables. This can be expected given that the motor structure of their game requires a high level of this ability in order to be able to implement the basic tactical tasks, primarily in the transition offence (defence), but also in the position offence (defence). Therefore, this ability is often treated in the majority of the total training time because it is trained during condition training and tactical training. However, the results of outer players are not statistically significantly better than the results of inner players. This suggests that inner players in modern basketball have the motor potential for quick running during the game and that frequent observations from practice that outer players are 'faster' than inner ones cannot be fully accepted. It is possible that outer players are 'faster' in some situations of the game, but in terms of motor potential inner players can be equally fast. The situation is similar regarding the test of fast change of direction and the way of movement. Outer players achieved better results on average but not statistically significantly better. This means that in this space as well, inner players have almost the same motor potential.

Table 2 Descriptive parameters of sub-samples: outer and inner players, and the values of t-test

\begin{tabular}{lccccccc}
\hline \multirow{2}{*}{ Variables } & \multicolumn{3}{c}{ Outside players (n=22) } & \multicolumn{2}{c}{ Inside players (n=13) } & t-test \\
\cline { 2 - 8 } & M \pm SD & Max. & Min. & M \pm SD & Max. & Min. & t \\
\hline TV (cm) & $193.63 \pm 5.10$ & 202.00 & 181.00 & $203.15 \pm 2.60$ & 208.00 & 199.00 & $-6.23^{* *}$ \\
TM (kg) & $90.12 \pm 8.58$ & 105.00 & 75.50 & $100.34 \pm 12.16$ & 122.00 & 85.50 & $-2.91^{* *}$ \\
BMI (kg/m $)$ & $24.05 \pm 1.99$ & 27.34 & 20.41 & $24.28 \pm 2.54$ & 28.24 & 20.63 & -.314 \\
S5m (s) & $1.05 \pm .054$ & 1.17 & .96 & $1.07 \pm .066$ & 1.18 & .98 & -1.18 \\
S10m (s) & $1.79 \pm .076$ & 1.95 & 1.68 & $1.82 \pm .090$ & 2.00 & 1.69 & -1.10 \\
S20m (s) & $3.03 \pm .10$ & 3.20 & 2.81 & $3.10 \pm .16$ & 3.48 & 2.90 & -1.67 \\
BPPA (s) & $9.05 \pm .34$ & 9.77 & 8.52 & $9.22 \pm .46$ & 10.50 & 8.82 & -1.23 \\
\hline$* *$ Sig. $(\mathbf{p}<\mathbf{0 . 0 1 )}$ & & & & & & \\
\hline
\end{tabular}


Table 3 shows correlations between all variables for the entire sample of basketball players. High correlations between acceleration variables and the variable of fast change of direction and the way of movement can be noticed. High correlations between acceleration variables are expected considering that a good start is a prerequisite to achieve the initial acceleration of $10 \mathrm{~m}$, and both are prerequisites for a good result on $20 \mathrm{~m}$. With the motor aspect, for the quality change of movement direction, a sufficient level of starting, accelerating, slowing and reactive power is required (Bompa, 1999). Since the starting (5m) and accelerating $(10 \mathrm{~m})$ and partly reactive power $(20 \mathrm{~m})$ are characteristic for the examined acceleration variables, their mutual correlation is understandable.

Table 3 Correlation between variables for the whole sample

\begin{tabular}{|c|c|c|c|c|c|c|c|}
\hline & TV & TM & $t 5 m$ & $\mathrm{t} 10 \mathrm{~m}$ & $\mathrm{t} 20 \mathrm{~m}$ & BPPA & BMI \\
\hline TV & 1 & & & & & & \\
\hline TM & $.619^{(* *)}$ & 1 & & & & & \\
\hline t5m & .313 & $.350^{(*)}$ & 1 & & & & \\
\hline $\mathrm{t} 10 \mathrm{~m}$ & $.383^{(*)}$ & $.467^{(* *)}$ & $.718^{(* *)}$ & 1 & & & \\
\hline $\mathrm{t} 20 \mathrm{~m}$ & .306 & $.514^{(* *)}$ & $.695^{(* *)}$ & $.819^{(* *)}$ & 1 & & \\
\hline BPPA & .189 & $.408^{(*)}$ & $.705^{(* *)}$ & $.666^{(* *)}$ & $.779^{(* *)}$ & 1 & \\
\hline BMI & .093 & $.838^{(* *)}$ & .222 & .328 & $.437^{(* *)}$ & $.375^{(*)}$ & 1 \\
\hline $\begin{array}{l}* * \text { Sig. }(\mathrm{p}<0.01) \\
* \text { Sig. }(\mathrm{p}<0.05)\end{array}$ & & & & & & & \\
\hline
\end{tabular}

However, from biomechanical aspect, training of linear speed and the speed of movement direction change are specific and cause limited transfer on one another (Buttifant, Graham, \& Cross, 1999; Draper, \& Lancaster, 1985: Mayhew, et al., 1989; Young, et al., 1996). The assumption is that linear speed training has less transfer to agility, the speed of direction change that requires decision making, or involves a complex operation specific for the sport, such as dribbling in basketball or dribbling penetration (Sheppard, \& Young, 2006). Compared to previous findings about non existing connection between variables of linear speed and variables of the speed of movement direction change, with different samples of athletes, different tests with their different structure (distances, number of movement direction changes), results in this study showed a high level of connection. The reasons could be seen in the facts: it was a highly trained sample with reduced sensitivity to the impact of training stimulus; in the motor structure of the basketball games both ways of movement (linear and that with a change of direction) are highly pres- ent and in the end, the thing that was not measured is the percentage of body fat in subjects as an important predictor of the ability of acceleration and the speed of movement direction change, which cannot be determined from the acquired BMI (body mass index). These results suggest that players have to train specifically those movement patterns that occur in their sport. Therefore, the researches confirm the fact that the linear speed is clearly different characteristic than the speed of direction change. However, if given sport, in this case basketball, significantly includes a linear sprint and movement direction changes, it is expected to appear more pronounced correlation between them, which was the finding and the assumption in this work. Medium number of correlations between morphological variables, body height $(\mathrm{BH})$ and body mass (BW) with variables of acceleration is understandable considering that in this phase, running speed is lower and approaches the value of $7 \mathrm{~m} \cdot \mathrm{s}^{-1}$, so longitudinal dimensionality, and thus caused the step length influences more the running speed than step frequency, which is later gradually lost by reaching higher speed 
$8-9 \mathrm{~m} \cdot \mathrm{s}^{-1}$ (Pajic, 2006). But the aggravating speed factor at that stage of running is body mass, considering that an athlete needs to overcome his inertia characteristics, i.e. to produce a rapid increase in work effort during first steps. Therefore, body height and body mass in this phase of running differently affect the acceleration variables. The correlation acquired between the variable of movement direction change and of body mass was expected since during the change in direction the moment of body inertia has to be controlled. So to say, a 'fatter' athlete has greater inertia due to larger amounts of fat, which requires greater force production per kilogram of lean body mass to perform a certain change in speed or movement direction (Sheppard, \& Young, 2006), and/or has lower lean body mass (LBM), which may have an impact on the speed requirements of the direction change. However, no significant difference was found in the variable of BMI, where the average values are very close. The reason lies in the fact that although there are differences in absolute values, the relationship between body height and body mass is almost identical in both groups. BMI is more than the indicator of weight, over the body mass component it indirectly indicates the amount of adipose tissue, especially in cases of extreme body masses (Malina et al. 2004). Compared to the values of body height and body mass of the subjects, it can be concluded that their relationship is optimal and shows a good body composition, which was expected considering the high quality level of the subjects.

Previous statements indicate that other morphological characteristics that may affect the speed of movement direction change should be explored as well. In addition to body height, these are also relative limb length, height of mass centre and percentage of adipose tissue. In addition, extra attention should be paid to the development of lower extremity strength, and methods of training that will favorably affect the upgrading of explosive movements (Kukrić, et al. 2009).

\section{CONCLUSION}

Linear movement speed (acceleration) and speed of change of direction and the way of movement (agility) were undeniably very important motor skills of basketball players. In basketball practice it is thought that outer players are better in these abilities in relation to inner players. Outer players displayed better results in variable of acceleration and agility than inner players, but not statistically significant. This means that inner players as well have a motor potential needed for quick running or moving that they can show in the games. Adequate training and tactical systems that a coach chooses should be directed to stimulate this ability with inner players. Basketball players need to train specifically with those movement patterns that occur in their sport.

A number of researches confirm the fact that the linear speed is clearly different ability than the speed of change of direction and movement. However, in this study, with basketball players, appeared more pronounced correlation between these abilities, which is probably due to the fact that basketball significantly involves a linear sprinting (acceleration), as well as changes of direction. This indicates the necessity to apply acceleration and agility exercises in training players. Uniformity of basketball quality of the subjects (national team players and candidates for the national team) can also be the cause of this connection of acceleration variables $(\mathrm{t} 5 \mathrm{~m}, \mathrm{t} 10 \mathrm{~m}$ and $\mathrm{t} 20 \mathrm{~m}$ ) and the agility variable (FCDA). 


\section{REFRENCES}

1. Ben Abdelkrim, N., ElFazaa, S., ElAti, J. (2007). Time-motion analysis and physiological data of elite under-19-zear-old basketball plazers during competition. British Journal of Sports Medicine, 41(2), 69-75.

2. Bompa, T.O. (1999). Periodization in sport. Champaign: Human kinetics

3. Buttifant, D., Graham, K., \& Cross, K. (1999). Agility and speed measurement in soccer players are two different performance parameters. In: Fourth World Congress of Science and Football. Sydney: University of Technology

4. Crisafulli, A., Melis, F., Tocco, F., Laconi, P., Lai, C., \& Concu, A. (2002). External mechanical work versus oxidative energy consumption ratio during a basketball field test. Journal of Sports Medicine \& Physical Fitness 42, 409417.

5. Delextrat, A. \& Cohen, D. (2008). Physiological testing of basketball players: toward a standard evaluation of anaerobic fitness. Journal of Strength and Conditioning Research, 22(4), 1066-1072.

6. Draper, J.A., \& Lancaster, M.G. (1985). The 505 test: A test for agility in horizontal plane. Australian Journal of Science and Medicine in Sport, 17(1), 15-18.

7. Draper, J., \& Pyke, F. (1988). Turning speed: A valuabe asset in cricket run making. Sports Caoch, 11(3), 30-31.

8. Erčulj, F., i Bračič, M. (2010b). Comparison of the morphological profiles of young European female basketball players from different competitive levels. Physical Culture, 64(2), 14-21.

9. Erčulj, F., Dežman, B., Vučkovič, G., \& Milič, R. (2002). Functional abilities of elite female basketball players in different playing positions. Acta Kinesiologae Universitatis Tartuensis, 7, $75-80$.

10. Karalejić, M., i Jakovljević, S. (2009). Dijagnostika u košarci. [Diagnostics in basketball] Beograd: 3D plus i VSZŠ́.
11. Kukrić, A., Karalejić, M., Petrović, B., \& Jakovljević, S. (2009). Effect of complex training on explosive strength of legs extensors in junior basketball players. Fizička kultura, 63(2), 165-180.

12. Malina, R.M. Bouchard, C., \& Bar-Or O. (2004). Growth, Maturation, and Physical Activity. Champaign (IL): Human Kinetics.

13. Mayhew, J.L., Piper, F.C., Schwegler, T.M., \& Ball, T.E. (1989). Contributions of speed. agility and body composition to anaerobic power measurements in college football players. The Journal of Applied Sport Science Research, 3(4), 101-106.

14. McInnes, S.E., Carlson, J.S., Jones, C.J., \& McKenna, M.J. (1995). The Physiological load imposed on basketball players during competition. Journal of Sports Sciences, 13, 387-97.

15. Narazaki, K., Berg, K., Stergiou, N., \& Chen, B. (2008). Physiological demands of competitive basketball. Scandinavian Journal of Medicine \& Science in Sports, Early View 1-8.

16. Pajić. Z. (2006) Efekti primene inercionih opterećenja na motoričke, morfološke i biomehaničke performanse kretanja maksimalnom brzinom. [Effects of application of inertial loads on the motor, morphological and biomechanical performance of a maximal speed movement]. (Doktorska disertacija) [Doctoral disertation]. Beograd: Fakultet sporta i fizičkog vaspitanja,.

17. Sheppard, J.M., \& Young, W.B. (2006). Agility literature review: Classification. training and testing. Journal of Sport Sciences, 24(9), 919932.

18. Spencer, M., Bishop, D., Dawson, B., \& Goodman, C. (2005). Physiological and metabolic responses of repeated-sprint activities specific to field-based tem sports. Sports Medicine, 35 (12), 1025-1044.

19. Stapff, A. (2000). Protocols for the Physiological Assessment of Basketball players. In Gore, C.J. (editor) Physiological Tests for Elite Athletes. Australian Sports Commission. Human Kinetics. Champaign:IL. 
20. Taylor, J. (2004). A tactical metabolic training model for collegiat basketball. Strength and Conditioning Journal, 26(5), 22-29.

21. Trninić, S. (1996). Analiza i učenje košarkaške igre. [Analysis and learning of basketball game]. Pula: Vitka

22. Trninic, S., \& Dizdar, D. (2000). System of the performance evaluation criteria weighted per positions in the basketball game. Collegium Antropologicum, 24(1), 217-234.

23. Trninić, S., Karalejić, M., Jakovljević, S, i Jelaska, I. (2010a). Structural analysis of knowledge based on principal attributes of the game of basketball. Physical Culture, 64(2), 22-41.
24. Trninić, S., Karalejić, M., Jakovljević, S, i Jelaska, I. (2010b). Structural analysis of knowledge based on specific attributes of the game of basketball. Physical Culture, 64(2), 22-41.

25. Young, W., \& Farrow, D. (2006). A review of agility: practical applications for strength and condiditoning. Strength and Conditioning Journal, 28(5), 24-29.

26. Young, W., Hawken, M., \& McDonald, L. (1996). Relationship between speed. agility and strength qualities in Australian rules football. Strength \& Condition Coach, 4(4), 3-6.

Received: 3.3.2010.

Accepted: 10.2.2011. 
Саша Јаковљевић

Миливоје Каралејић

Зоран Пајић

796.323 .054

Радивој Мандић

Изворни научни чланак

Факултет спорта и физичког васпитања Београд Универзитета у Београду

\title{
УБРЗАЊЕ И БРЗИНА ПРОМЕНЕ СМЕРА И НАЧИНА КРЕТАЊА КВАЛИТЕТНИХ КОШАРКАША
}

\begin{abstract}
Сажетак
Циљ ове студије је био да се испитају способност убрзања и агилност кошаркаша. Истраживање је спроведено на узорку од 35 професионалних бугарских кошаркаша (просечне старости $21.37 \pm 2.91$ година) који су се такмичили у Првој кошаркашкој лиги Бугарске и који су подељени у две групе у односу на позицију у игри: унутрашњи играчи $-\mathrm{H=13}$ и спољни играчи $-\mathrm{H}=22$. Они су изабрани, од стране експерата, као најбољи домаћи играчи Лиге. Примењена су два теста: трчање на 20 метара (убрзање Т20м) и Т-тест (агилност - ТT). Током теста трчање на 20м измерена су и времена трчања на 5 (Т5м) и 10 метара (Т10м). Осим тога су измерене телесна висина (ТВ) и телесна маса (ТM). Унутрашњи играчи су значајно виши и тежи од спољних играча, али у варијаблама убрзања и агилности нису пронађене статистички значајне разлике између ове две групе кошаркаша, са тим да су на свим тестовима спољашњи играчи постигли боље резултате. Пронађене су високе корелације између три варијабле убрзања (Т5м, Т10м и Т20м) и једне варијабле агилности (ТТ) - коефицијенти корелације од .666 до .819, на нивоу значајности од .01. Корелације између телесне висине и варијабли убрзања су умерене - коефицијенти корелације од .306 до .383, на нивоу значајности од .05, док су коефицијенти корелације између телесне масе и ових варијабли нешто већи .350 до .415 на нивоу значајности од .01, односно .05.
\end{abstract}

Кључне речи: СЕНИОРИ / 20М / Т ТЕСТ / КОРЕЛАЦИЈЕ / РАЗЛИКЕ

\section{УВОД}

Кошарка припада групи спортских игра, у коју се најчешће убрајају тзв. колективни (тимски) спортови који садрже непосредну „борбу” две групе људи, два тима. То је популарна спортска игра, а њена привлачност за гледаоце се, у основи, заснива на израженој динамици игре, променљивости и непредвидљивости ситуација у игри. Кошарка се издваја као изразито сложена игра, са веома специфичним структурним и функционалним особинама (Trninić, 1996). Она садржи интермитентне и веште кретне активности са сложеним захтевима комбинације индивидуалних вештина, тимске игре и мотивационих аспеката (Trni- nic, \& Dizdar, 2000). Структура кошаркашке игpe ce уобичајено посматра са аспекта врсте и трајања кретања кроз временско-кретну анализу уобичајених кретања и кроз анализу специфичних кошаркашких техничко - тактичких активности (Каралејић, и Јаковљевић, 2009). Успешност већег броја послова које кошаркашки обављају у игри се постиже брзим акцијама на релативно малом простору (Трнинић и сар., 2010б).

Временско-кретна анализа се односи на регистровање и бележење трајања и дужине пређених растојања извођењем уобичајених кретних структура са и без лопте. Тако су МекИнес и

16 Коресподенција са: Саша Јаковљевић, Факултет спорта и физичког васпитања Универзитета у Београду, Благоја Паровића 156, 11030 Београд, e-mail: sasa.jakovljevic@dif.bg.ac.rs 
сарадници (McInes, Carlson, Jones, \& McKenna, 1995) регистровали $997 \pm 183$ различитих акција појединца током кошаркашке утакмице, а Бен Абделкрим и сар. (Ben Abdelkrim, ElFazaa, \& ElAti, 2007) $1050 \pm 51$, након промена правила игре (смањено трајање напада са 30 на 24 секунде, смањено време за пренос лопте у предње поље са 10 на 8 секунди и дистрибуција игре у 4 четвртине уместо у два полувремена). Кошарка обилује великим бројем: убрзања, успорења, спринтева, брзих промена правца и скокова. Крисафули и cap. (Crisafulli, Melis, Tocco, Laconi, Lai, \& Concu, 2002) су пронашли да кошаркаши, током 40 минута трајања кошаркашке утакмице, пређу око 45005000 м различитим врстама кретања (промене смера и правца кретања, трчања, дриблинзи, одбрамбена кретања и скокови) и различитим, променљивим брзинама. Наразаки и сар. (Narazaki, Berg, Stergiou, \& Chen, 2008) дају податке да кошаркаши током утакмице 34\% времена проведу у трчању и скакању, 56,8 \% у ходању и $9 \%$ времена стоје у месту. Јасно је да се кошаркашка игра састоји од кратких али веома интензивних активности, испрекиданих дужим или краћим периодима пасивног или активног одмора, за време којих се кошаркаш опоравља (Spencer, Bishop, Dawson, \& Goodman, 2005; Taylor, 2004; Trninić, 1996). У односу на то, кошаркашка „жива“ активност се углавном дешава у максималном и субмаксималном интензитету. О интензитету активности кошаркаша током утакмице говоре подаци да приближно 75 \% „живог” времена игре кошаркаши проведу у активностима у којима пулс достиже вредности од 85\% и више од максималног пулса (Erčulj, Dežman, Vučkovič, Milič, 2002; McInes et al., 1995). Тренерима у кошарци се, због свега наведеног, саветује да избегавају коришћење вежби које трају дуже од 30 секунди у програмима кондиционе припреме, него да се фокусирају на кратке и интензивне активности и тестове као што су: вертикални скок, Т тест, спринтеви на врло кратким дистанцама (од 5 до 20 м) и слично (Delextrat, \& Cohen, 2008).

У односу на базичне моторичке структуре, кошарка спада у групу полиструктурних спортова у којима доминирају сложена просторна кретања. Кошаркаш мора да примени научене структуре кретања (елементе технике и тактике) у различитим ситуацијама, које се током игре мењају зависно од акција саиграча и противничких играча.
Брза праволинијска (и лучна) кретања и кретања са брзим променама правца и смера кретања, су скоро увек присутна у акцијама кошаркаша, појединачно или у различитим комбинацијама. Брзина промене правца кретања је од необичне важности у кошарци због великог броја атипичних ситуација које се појављују током игре. Осим тога кошаркаши веома често морају да промене и начин кретања (нпр. фронтална, латерална, кретања „уназад“). Они, уобичајено, треба да изведу вишеструке и брзе промене правца кретања на релативно малом простору. Отежавајући фактор је што истовремено треба да воде рачуна о техничком и тактичком аспекту тих кретања, јер ће само на тај начин њихове акције бити ефикасне. Због тога и кошаркашки тренинг обилује вежбама агилности, у којима се мења правац и начин кретања, као и вежбама убрзања, снаге, развоја перцепције и способности доношења оптималних одлука (Young, \& Farrow, 2006). Ток кошаркашке игре подразумева континуитет у фази напада и у фази одбране, односно у фазама транзиције (Трнинић и сар., 2010а). Високо развијена способност убрзања је од велике важности не само за спољне играче, него и за оне који играју на унутрашњим позицијама (центри). Разлог за то је све већи број тренера који, због већ поменутог скраћења вермена трајања напада у кошарци, фаворизују брзу транзицију у нападу, али и у одбрани. Идеја је да се кош постигне што пре (у ситуацијама игре 2 на 2 или 3 на 3), односно, пре него што се формира комплетна одбрана (игра 5 на 5). Са друге стране, у транзицијској одбрани је идеја да се што пре свих пет играча врати у поље одбране и организује одбрану у позиционој игри. То се не може постићи ако унутрашњи играчи нису у стању да брзо трче. У односу на димензије кошаркашког игралишта (28x15 м), односно, још краћег простора за игру (од коша до коша), њихова способност брзог трчања у ствари значи способност убрзања. За спољне играче се по правилу подразумева да брзо трче и убрзавају. Уопште, кошарка је игра натпросечно високих људи (Ерчуљ, и Брачић, 2010), а ту се истичу унутрашњи играчи те им треба посветити посебну пажњу у тренингу брзине.

Брзина праволинијског кретања и брзина промене правца кретања (агилност) су идентификовани као два специфична квалитета спортиста 
са међусобним ограниченим трансфером (Young, Hawken, \& McDonald, 1996). Постоји већи број истраживања која ту специфичност налазе у простору тестирања ових способности, истичући потребу разликовања између тестова брзине и агилности (Draper, \& Lancaster, 1985; Draper, \& Pyke, 1988; Mayhew, Piper, Schwegler, \& Ball, 1989).

Први циљ ове студије је био да се испитају способности убрзања и брзине промене смера кретања код професионалних кошаркаша (два типа играча - спољни и унутрашњи), а други да се испитају релације између те две способности.

\section{МЕТОД}

\section{Узорак испитаника}

Истраживање је спроведено на узорку од 35 професионалних бугарских кошаркаша (просечне старости $21.37 \pm 2.91$ година) који су се такмичили у Првој кошаркашкој лиги Бугарске. Они су изабрани, од стране кошаркашких експерата бугарске кошаркашке федерације као најбољи домаћи играчи Лиге. Узорак је подељен у два подузорка у односу на позицију у игри: спољни играчи (они који играју на позицијама 1, 2 и 3 - N=22), про-

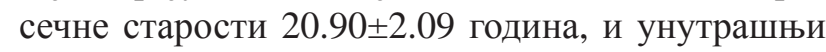
играчи (они који играју на позицијама 4 и 5 $\mathrm{N}=13)$, просечне старости 22.15 \pm 3.91 година.

\section{Узорак варијабли и процедура мерења}

Примењена су два теста: трчање на 20 метара спринтом и Т-тест.

Тест трчање на 20 метара спринтом је спроведен на означеној стази у кошаркашкој сали, са фотоћелијама (Micro Gate, Italy) позиционираним на 5, 10 и 20 метара од стартне линије и на висини од 1 метар. Испитаници су стартовали из стојећег става са истуреним стопалом на удаљености од 70 цм од прве фотоћелије и имали су задатак да што брже претрче дистанцу од 20 метара. На тај начин су добијене три варијабле, изражене у секундама (c): време трчања на 5 метара (т5м), време трчања на 10 метара (т10м) и време трчања на 20 метара (т20м).

T-mест (слика 1) представља често коришћен тест агилности од стране тренера и истраживача у спорту. Посебно је применљив у тестирању кошаркаша јер садржи кретања која су веома слична кретањима кошаркаша у игри. Потребна су четири конуса (сталка), штоперица или фото ћелије. Конуси су постављени као на слици 1. Испитаници су се пре извођења теста прописно загрејали и припремили. Мерилац или неко други демонстрира начин извођења. Сваки испитаник је тако био упућен да стартује, на знак мериоца, са тачке А и спринта до конуса Б, те да га дотакне десном руком. Затим се креће клизањем бочно (основно одбрамбено кошаркашко кретање) ка конусу Ц и додирује га левом руком. Потом се креће клизањем бочно до конуса Д и дотиче га десном руком. Поново иде ка конусу Б, додирује га левом руком и иде ка конусу А уназад (леђима) и када прође ниво конуса А региструје се време извођења целог теста. Изводе се два покушаја и вреди бољи резултат. Тако је добијена варијабла брзе промене праваца и начина кретања ( БППА).

Осим тога измерене су телесна висина (TB), користећи стадиометар (Sеса 220, UK) и телесна маса (TM), помоћу портабл ваге (Tanita BF683W, GER). Из ове две варијабле је израчуната варијабла „боди мас индех“ - БМИ (телесна

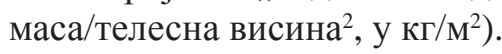

\section{Слика $1 \mathrm{~T}$ - тест}

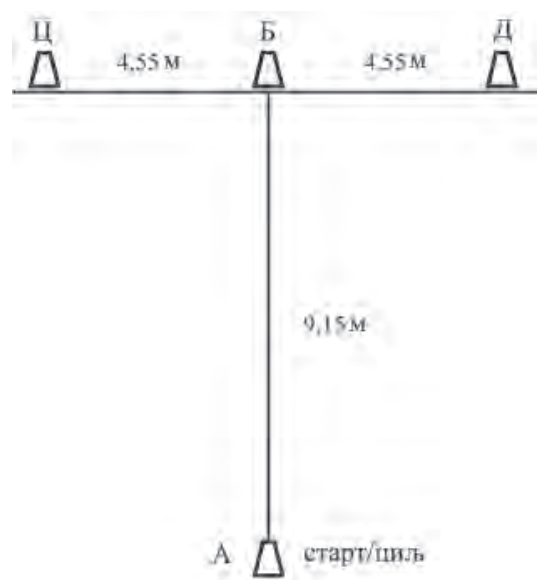

\section{Анализа података}

Подаци су обрађени најпре основном дескриптивном статистиком, где су израчунати: аритметичка средина (М), стандардна девијација (СД), минималне (Мин) и максималне вредности (Мax). Релације између варијабли су испитане помоћу Пирсоновог коефицијента корелације. У испитивању разлика између две групе кошаркаша је коришћен $m$ тест. Нивои значајности су постављени на $\mathrm{p}<0.05$. 


\section{РЕЗУЛТАТИ И ДИСКУСИЈА}

Табела 1 показује дескриптивне параметре свих варијабли за цео узорак. Поредећи са резултатима из доступне литературе може се рећи да су испитаници на дистанци од 5 метара постигли веома сличне резултате, (незнатно слабије) у односу на нпр. врхунске кошаркаше Аустралије, док су резултати трчања на 20 метара веома слични, скоро идентични (Stapff, 2000). Слично је и када су у питању телесна висина и телесна маса (Stapf, 2000).

Табела 1 Дескриптивни параметри свих варијабли за цео узорак

\begin{tabular}{ccccc}
\hline Варијабле & Мин. & Мах. & Меан & СД \\
\hline т5м (с) & .96 & 1.18 & 1.0586 & .059 \\
т10м (с) & 1.68 & 2.00 & 1.8034 & .081 \\
т20м (с) & 2.81 & 3.48 & 3.0566 & .129 \\
БППА (с) & 8.52 & 10.50 & 9.1143 & .395 \\
ТВ (цМ) & 181.00 & 208.00 & 197.1714 & 6.345 \\
ТМ (кг) & 75.50 & 122.00 & 93.9229 & 11.079 \\
БМИ (кг/м²) & 20.41 & 28.24 & 24.13 & 2.18 \\
\hline
\end{tabular}

Дескриптивни параметри подузорака: спољни играчи и унутрашњи играчи су дати у та- бели 2, као и вредности т-теста. Унутрашњи играчи су статситички значајно виши и тежи. То је очекивано с обзиром на уобичајену поделу улога у игри по позицијама.

У варијаблама убрзања боље резултате у просеку су показали спољни играчи. То је очекивано с обзиром да се у моторичкој структури њихове игре захтева висок ниво те способности да би се могли реализовати основни тактички задаци, а пре свега у транзицијском нападу (одбрани), али и у позиционом нападу (одбрани). Због тога се ова способност често третира у већем делу укупног времена тренинга, јер се увежбава и у кондиционом и у тактичком тренингу. Међутим резултати спољних играча нису статистички значајно бољи од резултата унутрашњих играча. То говори да унутрашњи играчи у модерној кошарци имају моторички потенцијал за брзо трчање током утакмице и да честе констатације из праксе да су спољни играчи „бржи“ од унутрашњих не могу да се прихвате у потпуности. Могуће је да су спољни играчи „бржи“ у ситуацијама игре, али са аспекта моторичког потенцијала унутрашњи играчи могу да буду једнако брзи.

Слична је ситуација и код теста брзе промене правца и начина кретања. Спољни играчи су постигли боље резултате у просеку али не статистички значајно боље. То значи да и у овом простору унутрашњи играчи имају скоро једнак моторички потенцијал.

Табела 2 Дескриптивни параметри подузорака: спољни и унутрашњи играчи, и вредности т-теста

\begin{tabular}{|c|c|c|c|c|c|c|c|}
\hline \multirow{2}{*}{ Вариајбле } & \multicolumn{3}{|c|}{ Спољни играчи (н=22) } & \multicolumn{3}{|c|}{ Унутрашњи играчи (н=13) } & \multirow{2}{*}{$\frac{\text { Т-тест }}{\mathrm{T}}$} \\
\hline & $\mathrm{M} \pm \mathrm{CД}$ & Max. & Мин. & $\mathrm{M} \pm \mathrm{CД}$ & Max. & Мин. & \\
\hline ТВ (цм) & $193.63 \pm 5.10$ & 202.00 & 181.00 & $203.15 \pm 2.60$ & 208.00 & 199.00 & $-6.23^{* *}$ \\
\hline ТМ (кг) & $90.12 \pm 8.58$ & 105.00 & 75.50 & $100.34 \pm 12.16$ & 122.00 & 85.50 & $-2.91 * *$ \\
\hline БМИ (кг/м²) & $24.05 \pm 1.99$ & 27.34 & 20.41 & $24.28 \pm 2.54$ & 28.24 & 20.63 & -.314 \\
\hline C5m (c) & $1.05 \pm .054$ & 1.17 & .96 & $1.07 \pm .066$ & 1.18 & .98 & -1.18 \\
\hline C10m (c) & $1.79 \pm .076$ & 1.95 & 1.68 & $1.82 \pm .090$ & 2.00 & 1.69 & -1.10 \\
\hline C20M (c) & $3.03 \pm .10$ & 3.20 & 2.81 & $3.10 \pm .16$ & 3.48 & 2.90 & -1.67 \\
\hline БППА (c) & $9.05 \pm .34$ & 9.77 & 8.52 & $9.22 \pm .46$ & 10.50 & 8.82 & -1.23 \\
\hline
\end{tabular}

$* *$ Sig. $(\mathrm{p}<0.01)$ 
У табели 3 су приказане корелације између свих варијабли за цео узорак кошаркаша. Могу се приметити високе корелације између варијабли убрзања и варијабле брзе промене правца и начина кретања. Високе корелације између варијабли убрзања су очекиване с обзиром да је добар старт услов да се постигне почетно убрзање на $10 \mathrm{~m}$, а обе су услов доброг резултата на 20м. Са мото- ричког аспекта, за квалитетну промену правца кретања потребан је задовољавајући ниво стартне, убрзавајуће, успоравајуће и реактивне снаге (Bompa, 1999). С обзиром да су стартна (5м) и убрзавајућа $(10 \mathrm{~m})$, а делом и реактивна снага (20м) карактеристичне за испитиване варијабле убрзања, разумљива је њихова међусобна висока корелација.

Табела 3 Повезаност варијабли за цео узорак

\begin{tabular}{|c|c|c|c|c|c|c|c|}
\hline & TB & TM & т5M & T10M & т20M & БППА & БМИ \\
\hline TB & 1 & & & & & & \\
\hline TM & $.619^{(* *)}$ & 1 & & & & & \\
\hline T5M & .313 & $.350^{(*)}$ & 1 & & & & \\
\hline T10M & $.383^{(*)}$ & $.467^{(* *)}$ & $.718^{(* *)}$ & 1 & & & \\
\hline T20M & .306 & $.514^{(* *)}$ & $.695^{(* *)}$ & $.819^{(* *)}$ & 1 & & \\
\hline БППА & .189 & $.408^{(*)}$ & $.705^{(* *)}$ & $.666^{(* *)}$ & $.779^{(* *)}$ & 1 & \\
\hline БМИ & .093 & $.838^{(* *)}$ & .222 & .328 & $.437^{(* *)}$ & $.375^{(*)}$ & 1 \\
\hline
\end{tabular}

Међутим, са биомеханичког аспекта тренинг праволинијске брзине и тренинг брзине промене смера кретања су специфични и проузрокују лимитиран трансфер један на другог (Buttifant, Graham, \& Cross, 1999; Draper, \& Lancaster, 1985; Mayhew, et al., 1989; Young, et al., 1996). Петпоставка је да тренинг праволинијске брзине има још мањи трансфер на агилност, брзину промене смера кретања који захтева доношење одлука, или укључује комплексну радњу специфичну за дати спорт, као што је нпр. дриблинг у кошарци или продор дриблингом (Sheppard, \& Young, 2006). У односу на претходне налазе о неповезаости варијабли праволинијске брзине и брзине промене смера кретања, са различитим узорцима спортиста, различитим тестовима са њиховом различитом структуром (дистанце, број промена смера кретања), налази у овој студији су указали на висок ниво повезаности. Разлози би се могли потражити у чињеницама: ради се о високо утренираном узорку са смањеним сензибилитетом на утицај тренажог стимулуса; у моторичкој структури кошаркашке игре су веома заступљена оба начина кретања (праволинијско и са променом правца) и на крају

није мерен постотак масног ткива код испитаника, као важан предиктор способности убрзања и брзине промене смера кретања, што се из добијеног БМИ не може утврдити.

Ови резултати сугеришу да кошаркаши морају тренирати специфично са оним кретним обрасцима који се јављају у њиховом спорту. Дакле, истраживања потврђују чињеницу да је праволинијска брзина јасно различита способност од брзине промене смера кретања. Међутим, уколико дати спорт, у овом случају кошарка, значајно укључује праволинијски спринт, као и промене смера кретања, онда је за очекивање да се појављује израженија корелација међу њима, што је и налаз и претпоставка у овом раду.

Умереност корелација између морфолошких варијабли телесне висине (ТВ) и телесне масе (ТM) са варијаблама убрзања је разумљива с обзиром да је у тој фази трчања брзина трчања мања, односно приближава се вредности од 7м.с-1, те лонгитудинална димензионалност, а тиме узро- 
кована и дужина корака више утиче на брзину трчања него фреквенција корака, што се касније постизањем веће брзине 8-9м.. ${ }^{-1}$ брзине постепено губи (Пајић, 2006). Међутим отежавајући фактор брзине у тој фази трчања је маса тела, с обзиром да спортиста треба да савлада своје инерционе карактеристике, тј. да произведе брз прираст радног напора у првим корацима. Дакле, телесна висина и маса тела у овој фази трчања различито утичу на варијабле убрзања. Очекивана је добијена корелација између варијабле промене смера кретања и телесне масе с обзиром да се приликом промене правца мора савладати моменат инерције тела. Условно речено, „дебљи” спортиста има већу инерцију услед веће количине масног ткива, што захтева већу продукцију силе по килограму безмасне масе, да би извео одређену промену у брзини или смеру кретања (Sheppard, \& Young, 2006), односно има мању безмасну тежину (енгл. lean body mass; LBM) која може имати утицај на брзинске захтеве промене смера кретања.

Међутим, није пронађена значајна разлика у варијабли БМИ, где су просечне вредности веома блиске. Разлог је у чињеници да иако постоје разлике у апсолутним вредностима, однос телесе висине и телесне масе је скоро идентичан код обе групе испитаника. БМИ је више од показатеља саме тежине, преко компоненте телесне масе индиректно указује и на количину масног ткива, посебно у случајевима екстермних телесних маса (Malina et al. 2004). У односу на вредности телесне висине и телесне масе испитаника може се закључити да је њихов однос оптималан и указује на добру телесну композицију, што је и очекивано с обзиром на висок ниво квалитета испитаника.

Претходни наводи указују да треба истражити и остале морфолошке карактеристике које могу имати утицај на брзину промене смера кретања. То су поред телесне висине и релативна дужина екстремитета, висина центра масе и проценат масног ткива. Осим тога, додатну пажњу треба посветити развоју снаге доњих екстремитета, односно методима тренинга који ће повољно утицати на усваршавање експлозивних кретанја (Кукрић и сар. , 2009).

\section{ЗАКЉУЧАК}

Брзина праволинијског кретања (убрзање) и брзина промене правца и начина кретања (агилност) су неоспорно веома важне моторичке способности кошаркаша. У кошаркашкој пракси влада мишљење да су спољни играчи квалитетнији у поменутим способностима у односу на унутрашње играче. Спољни играчи су показали боље резултате у варијаблама убрзања и агилности од унутрашњих играча, али не статистички значајно. То значи да и унутрашњи играчи имају моторички потенцијал потребан за брзо трчање, односно кретање, које могу показати и на утакмицама. Адекватан тренинг и тактички системи које тренер бира треба да буду усмерени на стимулисање ове способности код унутрашњих играча. Кошаркаши треба да тренирају специфично са оним кретним обрасцима који се јављају у њиховом спорту.

Већи број истраживања потврђује чињеницу да је праволинијска брзина јасно различита способност од брзине промене смера и кретања. Међутим, у овој студији се, код кошаркаша, појавила израженија корелација међу овим способностима, што је вероватно последица чињенице да кошарка значајно укључује праволинијски спринт (убрзање), као и промене смера кретања. То указује на неопходну потребу примене вежби убрзања и агилности у тренингу кошаркаша. Уједначеност кошаркашаког квалитета испитаника (репрезентативци и кандидати за репрезентацију) такође може да буде узрок овакве повезаности варијабли убрзања (т5м, т10м и т20м) и варијабле агилности (БППА). 


\section{ЛИТЕРАТУРА}

1. Ben Abdelkrim, N., ElFazaa, S., ElAti, J. (2007). Time-motion analysis and physiological data of elite under-19-zear-old basketball plazers during competition. British Journal of Sports Medicine, 41(2), 69-75.

2. Bompa, T.O. (1999). Periodization in sport. Champaign: Human kinetics

3. Buttifant, D., Graham, K., \& Cross, K. (1999). Agility and speed measurement in soccer players are two different performance parameters. In: Fourth World Congress of Science and Football. Sydney: University of Technology

4. Delextrat, A. \& Cohen, D. (2008). Physiological testing of basketball players: toward a standard evaluation of anaerobic fitness. Journal of Strength and Conditioning Research, 22(4), 1066-1072.

5. Draper, J.A., \& Lancaster, M.G. (1985). The 505 test: A test for agility in horizontal plane. Australian Journal of Science and Medicine in Sport, 17(1), 15-18.

6. Draper, J., \& Pyke, F. (1988). Turning speed: A valuabe asset in cricket run making. Sports Caoch, 11(3), 30-31.

7. Ерчуљ, Ф., и Брачич, М. (2010). Поређење морфолошких профила младих европских кошаркашица са различитих такмичарских нивоа. Физичка култура, 64(2), 14-21.

8. Erčulj, F., Dežman, B., Vučkovič, G., \& Milič, R. (2002). Functional abilities of elite female basketball players in different playing positions. Acta Kinesiologae Universitatis Tartuensis, 7, $75-80$.

9. Каралејић, М., и Јаковљевић, С. (2009). Дијагностика у кошарции. Београд: ЗД плус и ВСЗШ.

10. Кукрић, А., Каралејић, М., Петровић, Б., и Јаковљевић, С. (2009). Утицај комплексног тренинга на експлозивну снагу опружача ногу код кошаркаша јуниора. Физичка култура, 63(2), 165-180.

11. Malina, R.M. Bouchard, C., \& Bar-Or O. (2004). Growth, Maturation, and Physical Activity. Champaign (IL): Human Kinetics.
12. Mayhew, J.L., Piper, F.C., Schwegler, T.M., \& Ball, T.E. (1989). Contributions of speed. agility and body composition to anaerobic power measurements in college football players. The Journal of Applied Sport Science Research, 3(4), 101-106.

13. McInnes, S.E., Carlson, J.S., Jones, C.J., \& McKenna, M.J. (1995). The Physiological load imposed on basketball players during competition. Journal of Sports Sciences, 13, 387-97.

14. Narazaki, K., Berg, K., Stergiou, N., \& Chen, B. (2008). Physiological demands of competitive basketball. Scandinavian Journal of Medicine \& Science in Sports, Early View 1-8.

15. Пајић. 3. (2006) Ефекти примене инерционих оптерећења на моторичке, морфолошке и биомеханичке перформансе кретања максималном брзином. (Докторска дисертаuмја.) Факултет спорта и физичког васпитања, Београд.

16. Sheppard, J.M., \& Young, W.B. (2006). Agility literature review: Classification. training and testing. Journal of Sport Sciences, 24(9), 919-932.

17. Spencer, M., Bishop, D., Dawson, B., \& Goodman, C. (2005). Physiological and metabolic responses of repeated-sprint activities specific to field-based tem sports. Sports Medicine, 35 (12), 1025-1044.

18. Stapff, A. (2000). Protocols for the Physiological Assessment of Basketball players. In Gore, C.J. (editor) Physiological Tests for Elite Athletes. Australian Sports Commission. Human Kinetics. Champaign: IL.

19. Taylor, J. (2004). A tactical metabolic training model for collegiat basketball. Strength and Conditioning Journal, 26(5), 22-29.

20. Trninić, S. (1996). Analiza i učenje košarkaške igre. Pula: Vitka

21. Trninic, S., \& Dizdar, D. (2000). System of the performance evaluation criteria weighted per positions in the basketball game. Collegium Antropologicum, 24(1), 217-234. 
22. Трнинић, С., Каралејић, М., Јаковљевић, С, и Јеласка, И. (2010а). Структурна анализа знања на темељу основних атрибута кошаркашке игре. Физичка култура, 64(1), 5-23.

23. Трнинић, С., Каралејић, М., Јаковљевић, С, и Јеласка, И. (2010б). Структурна анализа знања на темељу специфичних атрибута кошаркашке игре. Физичка култура, 64(2), 22-41.

24. Crisafulli, A., Melis, F., Tocco, F., Laconi, P., Lai, C., \& Concu, A. (2002). External mechanical work versus oxidative energy consumption ratio during a basketball field test. Journal of Sports Medicine \& Physical Fitness 42, 409-417.
25. Young, W., \& Farrow, D. (2006). A review of agility: practical applications for strength and condiditoning. Strength and Conditioning Journal, 28(5), 24-29.

26. Young, W., Hawken, M., \& McDonald, L. (1996). Relationship between speed. agility and strength qualities in Australian rules football. Strength \& Condition Coach, 4(4), 3-6.

Примљен: 3.3.2010.

Прихваћен: 10.2.2011. 